\title{
Neocorynurella, a New Genus of Augochlorine Bees from South America (Hymenoptera: Halictidae)
}

\author{
Michael S. Engel ${ }^{1}$ and Barrett A. Klein ${ }^{2}$
}
1 Department of Entomology, Cornell University, Ithaca, New York

\section{Exhibitions, American Museum of Natural History, New York, New York}

\begin{abstract}
Neocorynurella Engel gen, n., a new sweat bee genus of the tribe Augochlorini (Halictidae), is described and figured from high altitudes in Colombia and Venezuela. The genus is distinguished from other augochlorine genera by the following combination of characters: galeal comb absent, epistomal sulcus obtuse, mouthparts not narrowed, preoccipital ridge rounded, pronotal dorsal and lateral ridges not carinate, pectinate inner hind tibial spur, strong basitibial plate, truncated marginal cell, and penis valve without a ventral prong. Two species are currently recognized in the group, Neocorynurella seeleyi Engel et Klein sp. $\mathrm{n}$. and $N$. viridis Engel et Klein sp. n. Modified key couplets are provided for Eickwort's key to the genera of Augochlorini in order to facilitate recognition of the new genus. The position of Neocorynurella in augochlorine phylogeny is briefly discussed.
\end{abstract}

Key words: Augochlorini, bees, montane, Neocorynurella, South America, taxonomy

\section{Introduction}

Bees of the tribe Augochlorini are restricted to the New World and have their greatest diversity in the tropics. The group is most easily recognized by the division of the pseudopygidial area of the female fifth tergum and by the absence of a pygidial plate in the male. The tribe is small, with approximately 500 described species, compared to its cosmopolitan sister tribe the Halictini (with over 2000 species). Despite their numerical size, the augochlorines exhibit a wide range of behavioral diversity. Eusociality, those societies with a sterile worker caste, has apparently evolved once in a monophyletic group of Augochlorini, with a single reversal in this clade to solitary behavior (Michener, 1990; Engel, 1996a, in prep; Danforth \& Eickwort, 1997). Several augochlorine genera are also nocturnal foragers (e.g., Megalopta and Megaloptidia), with this mode of life having apparently evolved at

${ }^{1}$ (Corresponding address): Department of Entomology, Comstock Hall, Cornell University, Ithaca, New York 14853, USA.

${ }^{2}$ Exhibitions, American Museum of Natural History, Central Park West at $79^{\text {th }}$ Street, New York, New York 10024, USA. 
least twice in the tribe. Cleptoparasitism and diverse nesting biologies (e.g., wood vs. soil nesting: reviewed in Eickwort \& Sakagami, 1979) have likewise arisen multiple times, making the tribe an excellent group for studies of behavioral evolution.

Eickwort (1969a) presented a generic revision of the tribe and, along with a second paper, provided the modern tribal diagnosis (Eickworl, 1969b). Since the time of Eickwort's seminal studies on the Augochlorini, only two genera have been added, the Brazilian genus Micrommation (Moure, 1969) and the fossil genus Oligochlora from Dominican amber (Engel, 1996b). Herein we propose a new genus for two new species of Augochlorini from montane regions of Colombia and Venezuela. This is done in order to make the generic name available for a forthcoming paper by the senior author on cladistic relationships in the Augochlorini (Engel, in prep).

\section{Material and Methods}

Material of the new taxa presented herein was compared with specimens of Augochlorini from the following institutions: Amcrican Muscum of Natural History, New York (J. G. Rozen, Jr., and E. Quinter); Bohart Museum of Entomology, University of California, Davis (L. S. Kimsey and L. A. Baptiste); Canadian National Collection, Ottawa (G. Gibson and L. Dumouchel); Comell University Insect Collection, Ithaca (J. K. Liebherr and E. R. Hoebeke); Michigan State University (F. Stehr); Museum of Comparative Zoology, Harvard University (P. Perkins and S. Cover); National Museum of Natural History, Smithsonian Institution (R. J. McGinley); Natural History Museum of Los Angeles County (R. R. Snelling); Snow Entomological Museum, University of Kansas, Lawrence (R. W. Brooks and C. D. Michener); and the Universidad Nacional de Colombia, Bogot (G. Nates-Parra).

The morphological terminology and format for the descriptions is generally based on Eickwort (1969 a). The following abbreviations are used in the descriptions: F, flagellomere; S, sternum; and T, tergum. All measurements were made using an ocular micrometer on a WILD-M5a microscope.

\section{Neocorynurella Engel gen. $\mathrm{n}$.}

(Habitus - Fig. 1)

Type species. Neocorynurella seeleyi Engel et Klein sp. n., present designation.

Female. Angle of epistomal sulcus obtuse. Clypeus and supraclypeal area protuberant and gently rounded (Fig. 2); over half of clypeus extending below lower tangent of compound eye. Scape long and thin. Malar area short (Fig. 2). Hypostomal ridge carinate, anterior angle rounded, very slightly projecting beyond posterior border of head; hypostomal bridge suture short, not coming to a central closure before posterior border of head. Inner orbit of compound eye moderately emarginate; eye hairs short. Ocelli not enlarged, without impressed line between and just behind lateral ocelli. Vertex slightly swollen behind ocelli, not ridged (Fig. 2). Preoccipital ridge gently rounded. Gena broad, much greater in width than compound eye in profile (Fig. 2). Labral basal elevation orbicular, strongly protuberant in profile; labral teeth absent; distal process narrowly triangular. Mandible with weakly defined subapical tooth. Maxillary palp not elongated; galeal comb absent, apex lobed, base of galea distal to base of stipes, inner strip of galea broad and with setac. Prementum not greatly narrowed; salivary plate well sclerotized, V-shaped brace present; labial palp segments $2+3$ longer than 1; glossa moderately long, about half length of prementum. Pronotal lateral angle slightly obtuse, not produced; dorsal ridge rounded; lateral ridge sharply angled but definitely not carinate. Mesoscutum broadly rounded anteriorly, mesoscutal lip 


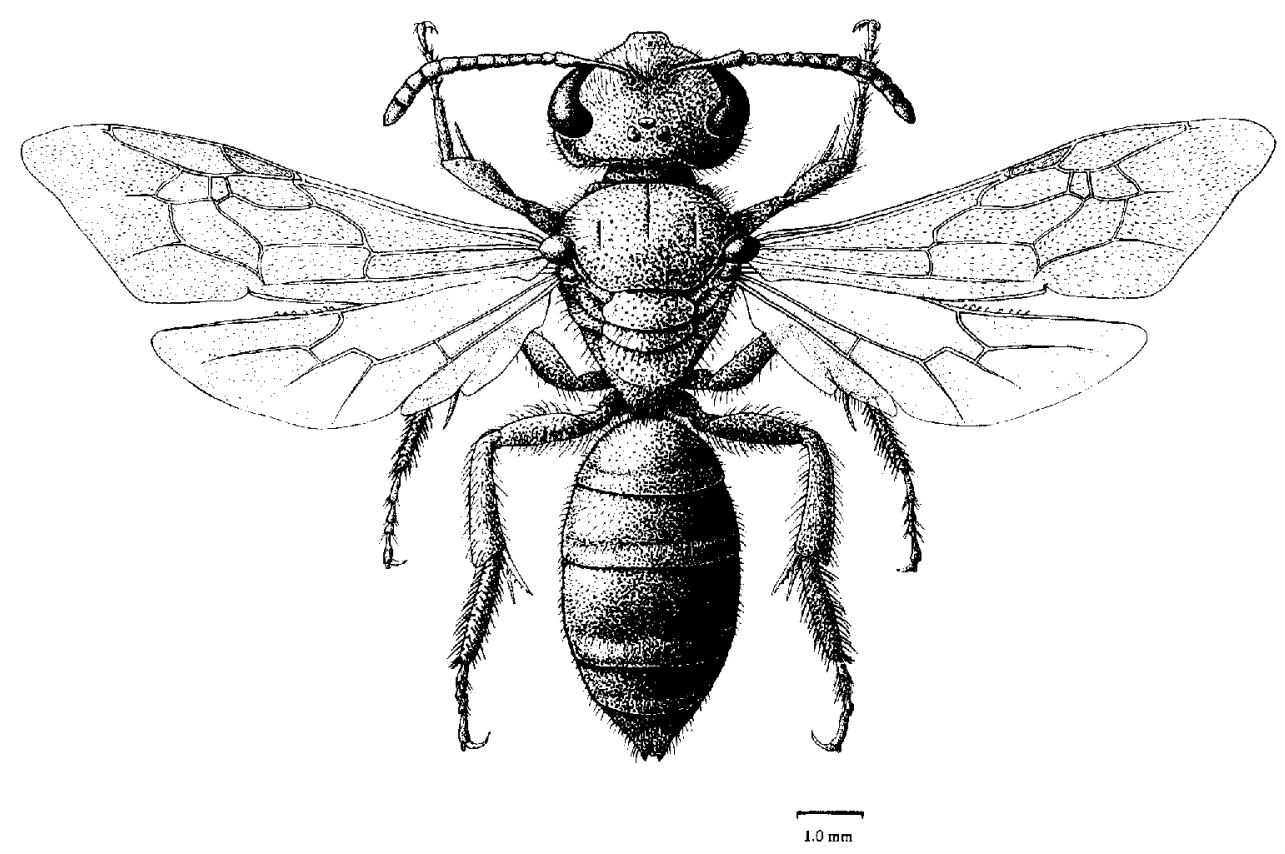

Fig. 1

Neocorynurella seeleyi: Female, dorsal habitus.

low and rounded, slightly projecting over pronotum; median and parapsidal lines strongly impressed. Tegula rounded normally. Propodeal triangle as long as metanotum, not declivious, with striae; pit of posterior face narrow; dorsal ridge rounded; lateral ridge rounded. Marginal cell weakly truncate and appendiculate. Anterior basitarsal brush present. Scopa formed of long, plumose hairs on hind trochanter and femur. Inner hind tibial spur pectinate, teeth short. Basitibial plate of moderate size, narrowly rounded, all borders strong. Pseudopygidial area of T5 divided, division deep and narrow.

Male. As for female except as indicated. Antenna long; scape of moderate length, shorter than in female; F2 longer than F1; sensory plate areas present. Labral basal elevation not notched; distal process short and broad. Mandible simple. Inner hind tibial spur serrate. Metasoma elongated, not petiolate. Pygidial plate of T7 absent. S4-5 with apical margins weakly depressed; S6 deeply emarginated along posterior margin (Fig. 3). Hidden fused sterna ( $\mathrm{S} 7-8$ ) as in Fig. 4; S7 with broad median projection; S8 with narrow median projection; spiculum of S8 broad. Male genitalia as in Figs 5-7. Gonobasal bridge narrow; dorsal lobes strong. Basal process of gonostylus and parapenial lobe absent. Ventral gonostylar process twisted at apex; dorsal gonostylar process a thin projecting plate with setae. Volsella without long, thin, apical median projection. Venter of penis valve without prong or keel.

Et y mology. The name Neocorynurella is a diminutive of the generic name Neocorynura.

Remarks. Neocorynurella superficially resembles the genera Corynura (Callistochlora), Augochlorodes, and Andinaugochlora. It can be readily separated from the first group by the absence of long eye hairs, absence of a galeal comb, and the strong border to the 
basitibial plate. The truncate marginal cell apex, pronotal dorsal ridge, larger body size, and sculpturing of the propodeal triangle will distinguish Neocorynurella from Augochlorodes. Neocorynurella most closely resembles species of the high elevation genus Andinaugochlora. Andinaugochlora, however, has an orthogonal to slightly acute epistomal sulcus, a carinate preoccipital ridge, an obsolescent anterior border to the basitibial plate, and a ventral prong on the ventral surface of the penis valve.

In Eickwort's key (1969a) to the genera and subgenera of Augochlorini, females of Netcorynurella will run to couplet 30 (under the genus Augochlorodes), whilc males will run to the same genus at couplet 23 . The following modified couplets are required in order to correctly identify this new taxon. Couplet numbers with a prime are new couplets which need to be inserted into Eickwort's keys after their corresponding numbers.

\section{Eickwort's key to females}

30 a. Hairs of compound eye long; basitibial plate obsolescent anteriorly, very short.

Corynura (Callistochlora) Michener

b. Hairs of compound eye short; basitibial plate well defined along all borders, of normal length.

$30^{\prime}$ a. Pronotal dorsal ridge strongly carinate; marginal cell apex acute; overall body size mode Couplet 30 rate (approx. $7 \mathrm{~mm}$ ).

Augochlorodes Moure

b. Pronotal dorsal ridge rounded, nol carinate; marginal cell apex Iruncate and appendiculate; overall body size large (approx. $11.5 \mathrm{~mm}$ ).

Neocorynurella Engel gen. $\mathrm{n}$.

\section{Eickwort's key to males}

23 a. Preoccipital ridge rounded.

b. Preoccipital ridge sharply angled or carinate.

Couplet 24

$\mathbf{2 3}^{\prime}$ a. Propodeal triangle smooth; S5 with dense clump of setae medially; S6 shallowly notched along apical margin; dorsal lobes of gonobase weakly defined; penis valve with ventral prong.

Augochlorodes Moure

b. Propodeal triangle with striae; S5 with scattered setae; S6 deeply notched along apical margin; dorsal lobes of gonobase strong; venter of penis valve without prong.

Neocorynurella Engel gen. $\mathrm{n}$.

\section{Key to the species of Neocorynurella}

1 a. Pronotal lateral surface weakly imbricate, without striae; hypoepimeron granular, without striac; head and mesosoma metallic red, with a few metallic green and coppery highlights.

N. seeleyi Engel et Klein sp. n.

b. Pronotal lateral surface with a few dorsoventral striat; hypoepimeron with weak transverse striae; head and mesosoma entirely brilliant metallic green.

N. viridis Engel el Klein sp. n. 
Neocorynurella seeleyi Engel et Klein sp. $\mathrm{n}$.

Figs $1-7$

Diagnosis. Head and mesosoma metallic red with coppery and green highlights. Pronotal lateral surface imbricate. Mesoscutal central disc with punctures more widely spaced than along lateral and posterior borders. Hypoepimeron granular.

Description.

Female. Total body length $10 \mathrm{~mm}$; fore wing length $7.7 \mathrm{~mm}$. Head wider than long (length $2.6 \mathrm{~mm}$; width $3 \mathrm{~mm}$ ). Distal two-thirds of clypeus extending beyond lower tangent of compound eyes; supraclypeal area as long as wide, slightly shorter than length of clypeus. Frontal line carinate just below antennal sockets to half of distance between antennal sockets and median ocellus, ending at that point. Scape long, reaching past lateral ocellus, length $1.2 \mathrm{~mm}$; pedicel slightly longer than wide, shorter than $\mathrm{F} 1$, length $0.18 \mathrm{~mm}$; F1 longer than wide, length $0.2 \mathrm{~mm}$; 2 about as long as wide, length $0.18 \mathrm{~mm}$; remaining flagellomeres slightly longer than wide; individual lengths of $\mathrm{F} 3-4,0.22 \mathrm{~mm}$; individual lengths of F5-9, $0.24 \mathrm{~mm}$; distal flagellomere, length $0.36 \mathrm{~mm}$. Median ocellus to lateral ocellus $0.1 \mathrm{~mm}$; median ocellus to antennal sockets $0.7 \mathrm{~mm}$; between lateral ocelli $0.3 \mathrm{~mm}$; lateral ocellus to compound eye $0.6 \mathrm{~mm}$. Compound eyes weakly convergent below. Prementum length $2 \mathrm{~mm}$; width $0.3 \mathrm{~mm}$; glossa length $1 \mathrm{~mm}$. Median and parapsidal lines strongly impressed. Intertegular distance $2.1 \mathrm{~mm}$. Scutellum 1.7 times longer than metanotum. Propodeal triangle as long as metanotum. Basal vein distad of cu-v crossvein by 4 times vein width; $1 \mathrm{r}-\mathrm{m}$ distad of $1 \mathrm{~m}$-cu by 2.5 times vein width; $2 \mathrm{r}-\mathrm{m}$ distad of $2 \mathrm{~m}$-cu by 8.5 times vein width. First submarginal cell slightly shorter than second and third combined; second submarginal cell not narrowed anteriorly; anterior border of second submarginal cell along Rs approximately equal to length of anterior border of third submarginal cell; length of anterior border of third submarginal cell less than half the length of posterior border; wings hyaline. Distal hamuli arranged 4-1-1-2. Inner hind tibial spur pectinate, with 6 teeth (not including apex as a tooth). Metasoma unmodified.

Mandible and labrum black. Face metallic red with a few metallic green and coppery highlights, except clypeal apex black; antenna black; clypeus with weak punctures $1-2$

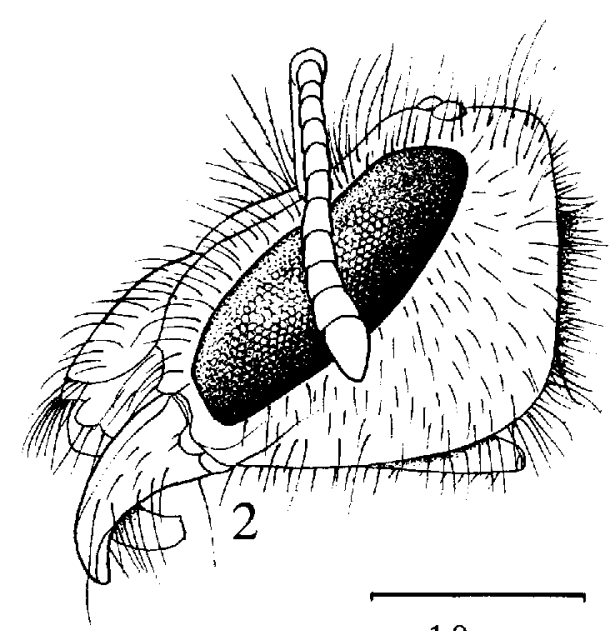

$1.0 \mathrm{~mm}$
Fig. 2

Neocorynurella seeleyi: Female, profile of head. 


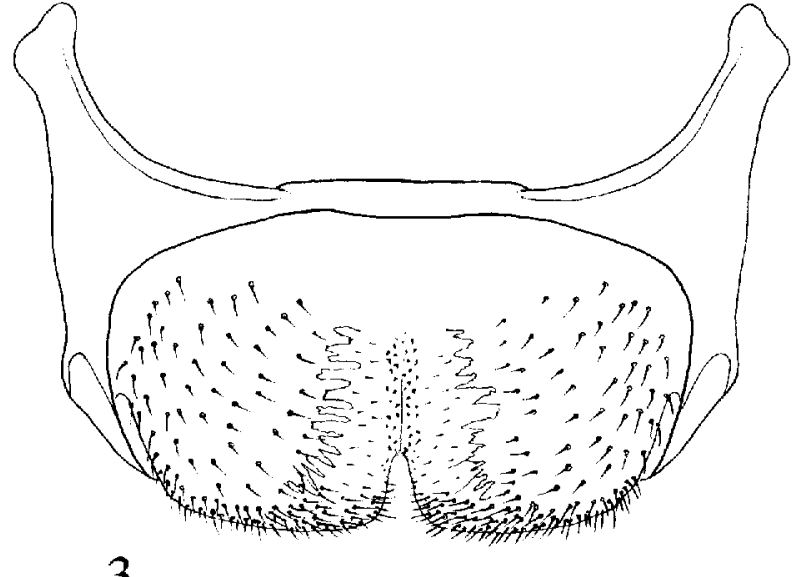

3

$1.0 \mathrm{~mm}$

Fig. 3. Neocorynurella seeleyi: Male, sternum 6 .

puncture widths apart, integument between imbricate; supraclypeal area and lower half of face as on clypeus, except integument between punctures granular; sculpture of upper half of face and vertex closely punctate, punctures strong and contiguous. Metallic red giving way to metallic green and gold on gena and postgena; gena imbricate with scattered punctures; postgena imbricate and impunctate. Pronotum dark brown with strong green and coppery highlights; collar smooth; lateral surface weakly imbricate. Mesoscutum, scutellum, and metanotum metallic red with coppery highlights, some green highlights along borders; tegula dark brown; mesoscutum closely punctured on borders, except anterior median region imbricate and impunctate, centrally punctures separated by $1-3$ puncture widths, integument between smooth; scutellum punctured, punctures separated by $1-2$ puncture widths, integument between smooth; metanotum minutely punctured, punctures separated by a puncture width or less. Pleura metallic red with coppery highlights, giving way to metallic green and gold ventrally; pre-episternum and mesepisternum granular, with a few, scattered, faint punctures; metepisternum transversely striate near wing base, otherwise granular. Propodeum metallic red with coppery highlights; propodeal triangle with striae radiating from basal margin, striae reaching two-thirds of way to apical margin, integument between finely

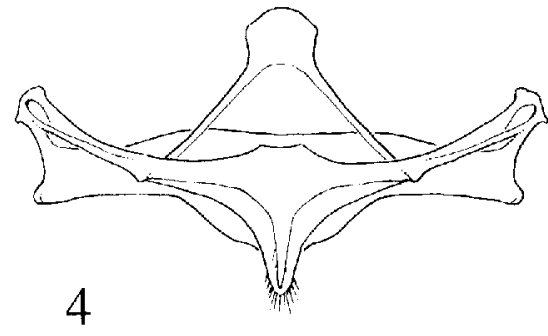

$0.5 \mathrm{~mm}$
Fig. 4. Neocorynurella seelevi: Male, sterna 7 and 8. 

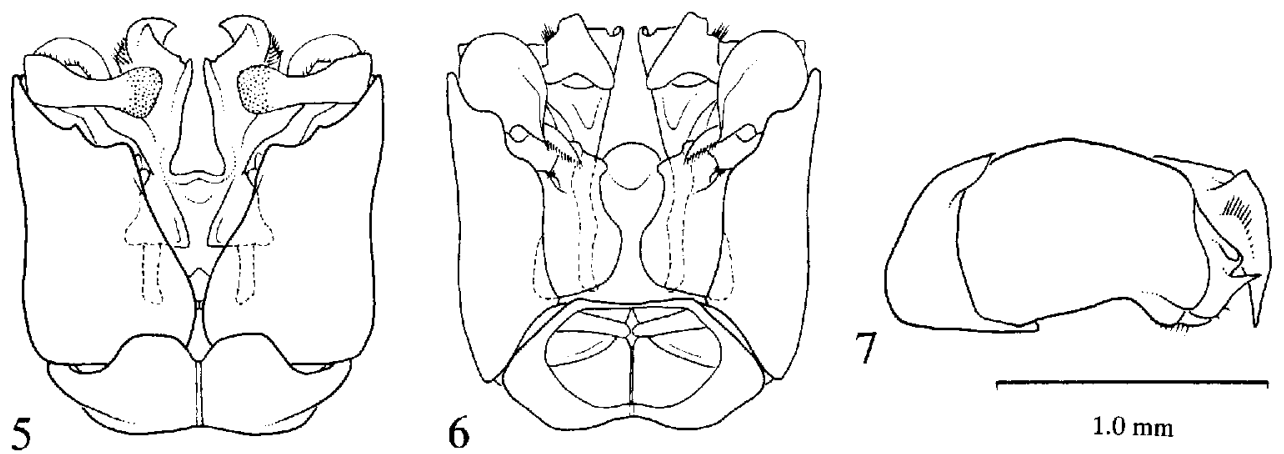

Figs 5-7. Neocorynurella seeleyi: Male genitalia, 5) dorsal aspect, 6) ventral aspect, 7) lateral aspect.

imbricate; lateral surface imbricate; posterior surface with transverse striae, integument otherwise imbricate. Forelegs dark brown; mid-legs dark brown, except tarsus lighter brown; hind legs lighter brown; weak metallic green highlights on coxae and trochanters. Terga and sterna dark brown and imbricate, terga with scattered metallic green or coppery highlights.

Hairs of face long, fuscous, and with a few short branches; hairs similar on gena, only lighter and shorter; postgena with scattered long, pale, plumose hairs. Mesoscutum, scutellum, metanotum, and pleura with scattered long, fuscous hairs, each with a few short branches. Propodeal triangle without pubescence; lateral and posterior surfaces with scattered, long, pale, plumose hairs. Pubescence of legs generally lighter than that of body; long branched hairs on posterior surfaces of profemur, protrochanter, and mesotrochanter; scopal hairs golden; dense, stiff, black hairs at apex of mesotibia and on outer surface of metatibia below basitibial plate. Tergal hairs scattered, short and fuscous, such hairs becoming longer on lateral margins and apical terga; sternal hairs pale, long and restricted to posterior halves of sterna.

Male. As for female except as follows. Total body length $10 \mathrm{~mm}$; fore wing length $7.8 \mathrm{~mm}$. Head about as long as wide (length $2.8 \mathrm{~mm}$; width $2.7 \mathrm{~mm}$ ). Distal three-quarters of clypeus projecting beyond lower tangent of compound eyes; supraclypeal area wider than long, much shorter than clypeus. Scape shorter than in female, just reaching lateral ocellus, length $0.9 \mathrm{~mm}$; pedicel about as long as wide, length $0.2 \mathrm{~mm} ; \mathrm{Fl}$ about as long as wide, length 0.2 ; remaining flagellomeres much longer than wide; F2, length $0.36 \mathrm{~mm} ; \mathrm{F} 3$, length $0.38 \mathrm{~mm} ; \mathrm{F} 4-5$, individual lengths $0.42 \mathrm{~mm}$; F6-8, individual lengths $0.46 \mathrm{~mm}$; F9-10, individual lengths $0.48 \mathrm{~mm}$; distal flagellomere, length $0.6 \mathrm{~mm}$. Male terminalia as in Figs 5-7. Second submarginal cell slightly narrowed anteriorly; anterior border of second submarginal cell along Rs half as long as anterior border of third.

Integument sculpturing and coloration as for femalc, except undersides of flagellomeres light brown and metallic green highlights of coxae and trochanters stronger.

General sex differences in pubescence (e.g., absence of scopal hairs) with the following addition: stiff, black hairs of mid- and hind legs absent.

Etymology. The specific epithet is a patronym honoring Dr. Thomas D. Seeley, Cornell University, for his friendship and guidance of our studies.

Material examined. Holotype female: VENEZUELA, Páramo, Las Cruces, Merida 3900-4300 m, P. Berry, 592, 1983 (Cornell University Insect Collection). 1 paratype male: 
VENEZUELA, Páramo, Las Cruces, Merida, 3900-4300 m, P. Berry, 591, 1983 (Cornell University Insect Collection). 1 paratype female: [COLOMBIA] Tunja Boyaca, Santuario, Iguaque, Morronegro, 15 Enc 1991, C. Sarmicnto, $2800 \mathrm{msnm}$ (Cornell University Insect Collection). 1 paratype female: [COLOMBIA] Cundinamarca, Bogot, Páramo de Monserrate, 3230 m, 7 September 1978, H. Sturm, specimen number 3820 (Universidad Nacional de Colombia).

Remarks. 1 female was destroyed in postal transit. The collection information for this specimen was: [Colombia] Tunja Boyaca, Santuario, Iguaque, Esterillal, 15 Ene 1991, C. Sarmicnto, $2800 \mathrm{msnm}$.

\section{Neocorynurella viridis Engel et Klein sp. n.}

Diagnosis. Head and mesosoma metallic green. Pronotal lateral surface with a lew dorsoventral striae. Mesoscutal central disc with punctures spaced similar to those of lateral and posterior borders. Hypoepimeron with transverse striae.

Description. As for $N$. seeleyi with the following modifications:

Female. Total body length $12.4 \mathrm{~mm}$; fore wing length $8 \mathrm{~mm}$. Head wider than long (length $2.8 \mathrm{~mm}$; width $3.3 \mathrm{~mm}$ ). Scape long, reaching past lateral ocellus, length $1.4 \mathrm{~mm}$; pedicel longer than wide, longer than $F 1$, length $0.22 \mathrm{~mm} ; F 1$ longer than wide, length $0.2 \mathrm{~mm}$; F2 about as long as wide, length $0.18 \mathrm{~mm}$; remaining flagellomeres slightly longer than wide; individual lengths of $\mathrm{F} 3-5,0.22 \mathrm{~mm}$; individual lengths of $\mathrm{F} 6-8,0.24$ $\mathrm{mm}$; F9, length $0.26 \mathrm{~mm}$; distal flagellomere, length $0.38 \mathrm{~mm}$. Median ocellus to lateral ocellus $0.1 \mathrm{~mm}$; median ocellus to antennal sockets $0.8 \mathrm{~mm}$; between lateral ocelli $0.3 \mathrm{~mm}$; lateral ocellus to compound eye $0.6 \mathrm{~mm}$. Intertegular distance $2.3 \mathrm{~mm}$. Basal vein distad of cu-v crossvein by 3 times vein width; $1 \mathrm{r}-\mathrm{m}$ distad of $1 \mathrm{~m}$-cu by 2 times vein width; $2 \mathrm{r}-\mathrm{m}$ distad of $2 \mathrm{~m}-\mathrm{cu}$ by 11 times vein width. First submarginal cell about as long as second and third combined. Inner hind tibial spur pectinate, with 8 teeth (not including apex as a tooth).

Head entirely brilliant metallic grcen with few coppery highlights, except clypeal apex black; clypeus and supraclypeal area with brassy highlights. Mesosoma entirely brilliant metallic grcen. Pronotal lateral surface with a few dorsoventral striae. Mesoscutal borders and centrally closely and cvenly punctured, punctures not more widely spaced centrally, except anterior median region as in $N$. seeleyi. Tegula dark brown with strong metallic green highlights on inner margin. Hypoepimeral area of mesepisternum with weak transverse striae, otherwise granular. Legs dark brown, except mesotarsus, metatibia, and metatarsus light brown; metallic green highlights on procoxa, protrochanter, and profemur. Terga and sterna dark brown; terga with strong metallic green highlights over entire surlace, except apical margins.

Male. Unknown.

Litymology. The specific epithet is the Latin word, viridis, meaning "green" and is a reference to the brilliant metallic green color of the species.

Material examined. Holotype female: VENEZUELA, DF Parque de Avila, 17 September 1966, R.L. Dressler (Cornell University Insect Collection). 1 paratype female: [VENEZUELA], DF Galipain, 30 April 1939, G. Vinas-Berthier (Cornell University Insect Collection). 


\section{Discussion}

A cladistic analysis of generic relationships in the Augochlorini has been completed by the senior author (Engel, 1996a, in prep) and the phylogenetic placement of Neocorynurella will be presented in full at a later time. However, a brief comment on its position and relatives seems appropriate here. Neocorynurella is a relatively basal member of the tribe. The combination of an obtuse epistomal sulcus, rounded preoccipital ridge, lobed galeal apex, unmodified mouthparts, and the generally unmodified male sterna excludes this genus from the large derived clades which contain most augochlorine genera (e.g., Augochlora, Augochloropsis, Megalopta, Pseudaugochlora). Despite the genus' more primitive position in augochlorine phylogeny, it does not fall within the basal clade of augochlorines containing the genera Halictillus, Corynura s.l., Rhectomia, and Rhinocorynura due to the absence of a strong galeal comb. Neocorynurella is apparently the closest relative of the high Andean genus Andinaugochlora. Both genera share a projecting posterior border to the hypostomal ridge, a truncated marginal cell apex, a strong gradulus on the male T7, a depressed apical margin to the male S5, and a broad spiculum on S8.

\section{Acknowledgments}

We are indebted to the various museum curators mentioned above, either for loans of material or for graciously hosting MSE during visits to their institutions. We are grateful to Dr. G. Gibson, Canadian National Collection, and two anonymous reviewers who offered critical reviews of an carlicr draft of the manuscript. Their comments helped in improving subsequent versions. Support for this project was provided by a National Science Foundation Predoctoral Fellowship (to MSE). The generic description is taken from a monograph of the augochlorine genera and subgenera being completed by MSE as part of a doctoral dissertation at Cornell University.

\section{References}

Danforth, B. N. \& Eickwort, G. C. (1997): The cvolution of social behavior in the augochlorine sweat bees (Hymenoptera: Halictidae) based on a phylogenetic analysis of the genera. In Choe, J. C. \& Crespi, B. J. (Eds.): The Evolution of Social Behavior in Insects and Arachnids. Cambridge University Press, Cambridge.

Eickwort, G. C. (1969a): A comparative morphological study and generic revision of the augochlorine bees (Hymenoptera: Halictidae). University of Kansas Science Bulletin, 48: 325-524.

- (1969b): Tribal positions of western hemisphere green sweat bees, with comments on their nest architecture (Hymenoptcra: Halictidae). Annals of the Entomological Society of America, 62: 652-660.

Eickwort, G. C. \& Sakagami, S. F. (1979): A classification of nest architecture of bees in the tribe Augochlorini (Hymenoptera: Halictidae; Halictinae), with description of a Brazilian nest of Rhinocorynura inflaticeps. Biotropica, 11: $28-37$.

Engel, M. S. (1996a): Phylogeny of the sweat bec tribe Augochlorini (Hymenoptera: Halictidae), with implications for social evolution. Proceedings of the $20^{\text {th }}$ International Congress of Entomology, Florence, 1996: 416.

- (1996b): New augochlorine bees (Hymenoptera: Halictidae) in Dominican amber, with a brief review of fossil Halictidae. Journal of the Kansas Entomological Society, supplement, 69: 334-345.

Michener, C. D. (1990): Reproduction and castes in social halictine bees, pp. 77-121. In Engels, W. (Ed.): Social Insects. An Evolutionary Approach to Castes and Reproduction. Springer Verlag, Berlin.

Moure, J. S. (1969): Micrommation, nôvo gênero de Halictidae do Paraná (Hym. Apoidea). Atas Sociedade de Biologia (Rio), 12: 247-249. 